\title{
DIFFERENCES OF CONFIRMATORY CASE, MORTALITY RATE AND INCIDENT MORTALITY OF COVID-19 IN INDONESIA, ASIA AND WHO ONLINE DATA CASE STUDY
}

\author{
Nugroho Susanto \\ Public Health Department, Faculty Health Science, Respati University of Yogyakarta, Jl Raya Tajem KM 1.5 \\ Maguwoharjo, Depok Sleman, 55282, Yogyakarta, Indonesia
}

\begin{abstract}
Turkish Ministry of Health estimated that $6.3 \%$ cases of COVID-19 fatality in April 2020 and $2.1 \%$ cases of COVID-19 mortality are associated with multi-factors. COVID-19 is very dangerous for moderate respiratory infection and has higher mortality compared to other diseases such as SARS-CoV-2. The study aims to compare case confirmation, mortality and compare incidence rate mortality between Indonesia and the world's general situation. The study designs used a cross-sectional study with secondary data. The study population was people who have been diagnosed to covid-19 based on the website with URL: https://covid19.who.int/ and URL: https://covid19.kemkes.go.id/ for the period of March 2020 to November 2020. The Independent Variables are areas of disease i.e. Indonesia, Asia, and world area. Statistical analysis was performed using SPSS. Data were analyzed with ANOVA. Average of confirmatory covid-19 is

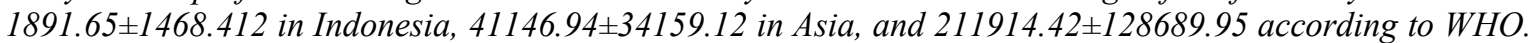

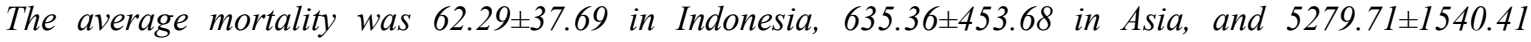
according to $\mathrm{WHO}$. The incidence mortality rate was $0.046 \pm 0.0326$ in Indonesia, averaged $0.023 \pm 0.0157 \mathrm{in}$ Asia, and averaged $0.035 \pm 0.0231$ according to WHO. There was a significant difference in confirmatory case between Indonesia, Asia and WHO with $p<0.001$, a significant difference in mortality between Indonesia, Asia and WHO with $p<0.001$, and significant difference in incidence mortality between Indonesia, Asia, and Indonesia with $p<0.001$. The study was concluded that there are significant differences in confirmatory case, death, and incident mortality between Indonesia, Asia and WHO. Confirmatory case and mortality were higher in WHO and Asia when compared to Indonesia, but incidence mortality was high in Indonesia when compared to WHO and Asia.
\end{abstract}

Keyword: COVID-19, incident, mortality, differences

\begin{abstract}
ABSTRAK
Department Kesehatan Turki mencatat bahwa kasus COVID-19 sebesar 6,3\% pada April 2020, dan 2,1\% kematian COVID-19 terkait dengan berbagai faktor. COVID-19 merupakan penyakit berbahaya pada saluran pernafasan dengan kematian lebih tinggi dibanding dengan penyakit SARS-CoV-2. Penelitian ini bertujuan mengetahui perbedaan konfirmasi kasus, kematian dan insiden kematian COVID-19 di Indonesia, Asia, dan WHO. Rancangan penelitian mengunakan cross sectional dengan data sekunder. Populasi penelitian adalah subjek yang telah dilaporkan didiagnosis COVID-19 berdasarkan laman website URL: https:/covid19.who.int/ dan URL: https://covid19.kemkes.go.id/ periode Maret 2020 sampai November 2020. Variabel independent dibagi menjadi indonesia, Asia, dan WHO. Uji statistik dilakukan menggunakan perangkat lunak SPSS. Data dianalisis dengan uji ANOVA. Rerata konfirmasi COVID-19 adalah $1891.65 \pm 1468.412$ di Indonesia, 41146.94 \pm 34159.12 di Asia, dan 211914.42 \pm 128689.95 di WHO. Angka kematian 62.29 \pm 37.69 di Indonesia, 635.36 \pm 453.68 di Asia, dan 5279.71 \pm 1540.41 di WHO. Angka insiden kematian $0.046 \pm 0.0326$ di Indonesia, $0.023 \pm 0.0157$ di Asia, dan $0.035 \pm 0.0231$ di WHO. Terdapat perbedaan signifikan konfirmasi kasus COVID-19 Indonesia, Asia dan WHO $\mathrm{p}=0,000$. Angka kematian Indonesia, Asia dan WHO terdapat perbedaan signifikan $p=0,000$. Angka insiden kematian antara Indonesia, Asia, dan WHO terdapat perbedaan signifikan $\mathrm{p}=0,000$. Hasil penelitian memberikan kesimpulan bahwa terdapat perbedaan yang signifikan konfirmasi kasus, kematian dan insiden kematian antara Indonesia, Asia dan WHO. Konfirmasi kasus, kematian kasus lebih tinggi di WHO dan Asia dibanding Indonesia, tetapi insiden kematian lebih tinggi di Indonesia dibanding Asia dan WHO
\end{abstract}

Kata Kunci: COVID-19, insiden, mortality, perbedaan

Correspondece Address: Nugroho susanto, ublic Health Department, Faculty Health Science, Respati University of Yogyakarta, Jl Raya Tajem KM 1.5 Maguwoharjo, Depok Sleman, 55282, Yogyakarta, Indonesia, E-mail: nugroho_susanto@respati.ac.id 


\section{Introduction}

COVID-19 is still a problem in all countries in the world. WHO (World Health Organization) have had reported almost 85.403 patients in 57 countries/territories, with 2.924 death cases, were addressed $97.1 \%$ of deaths occured in China. ${ }^{1,2}$ WHO reported that SARS-CoV-2 infected 381.000 people in 195 countries with estimated 16.000 deaths. ${ }^{1}$ Study ${ }^{3}$ reported a fatality rate of $6.3 \%$ on April 13, 2020. The Ministry of Health of Turkey had reported case fatality rate of $2.1 \%$ through COVID-19 mortality associated with multi-factors.

Previous study ${ }^{4}$ in China stated that $97.1 \%$ case of death were through contact transmission in public. The story of the SARS-Cov viruses has infected 8.098 cases with 9\% mortality, compared to COVID-19 that infected 120,000 cases through case death rate of $2.9 \%$. This condition made COVID-19 more dangerous than SARS-Cov. A study in Taiwan ${ }^{5}$ found that 45.167 cases of COVID-19 have been estimated in 28 regions with 1115 (2.5\%) death cases. The mortality rate of COVID-19 in the infected area were more likely occur to medical staffs. The study ${ }^{6}$ estimated the mortality rate for medical staff of 1688 cases, there were $0.3 \%$ death case.

Previous study ${ }^{6}$ have compared COVID-19 with others such as MERS, SARS-CoV. It showed that SARS and MERS had lower mortality rate compared to COVID-19. Since the outbreak in China, the novel COVID-19 has been confirmed which was previously not identified. The difference identified cases such as middle east respiratory syndrome COVID-19 in 2012 to 2015 and severe acute respiratory syndrome COVID-19 in 2003. Based on the study, it was confirmed and announced that COVID-19 pneumonia infection was category B while COVID-19 was category A.

The incubation period of COVID-19 is important for disease strategy interventions. The study $^{3}$ concluded that COVID-19 has an average incubation period of 5.2 (Confidence Interval: 4.1-12.5). This is similar to MERS and SARS. The study ${ }^{7}$ shows that the median was approximately 4-5 days before the onset of symptoms and the symptoms develop within 11.5 days. COVID-19 is very dangerous for moderate respiratory infection, especially for those aged 50 years or above. ${ }^{3}$ Based on the review ${ }^{8}$, COVID-19 caused immune response pathology. This condition caused high mortality rate of COVID-19. Study ${ }^{6}$ shows that COVID-19 is a new disease with population susceptibilities.

COVID-19 is transmitted via droplets and contact, based study concludes that the population is generally susceptible. Previous study ${ }^{9}$ that average is 5.2 days (4.1-7.0). Previous study ${ }^{6}$ in China that transmission from 10-24 January 2020 was increasing incidence and average reproduction 
number $(R 0)$ is $2.24(95 \%$ CI $1.96-2.55)$ to 3.58 (95\% CI $2.89-4.39)$. Study ${ }^{10}$ concludes that transmission among household contacts is $30 \%$.

The prevention strategy for COVID-19 such as controlling the inflammatory response and virus transmission concern. Immune responses have been imported for inhibiting viral infection ${ }^{8}$. Previous study ${ }^{10}$ shows that COVID-19 is transmitted by contact with the people who have been infected, and the strategy to curb COVID-19 is through quarantine and stay at home. Based on social interventions, the implementation for social distancing decreased COVID-19 transmission. Study ${ }^{11}$ showed that households transmission and family cluster have been reported.

The previous study ${ }^{12}$ showed that the risk factors for virus contact with physical distance of $>1$ meter had $\mathrm{aOR}=0 \cdot 18(\mathrm{CI} ; 0 \cdot 09-0 \cdot 38)$, the protection increased with physical distancing of 2,02 meters. Physical distancing of more than 1 meter is advised by government policy stakeholder. Strategy with the vaccine to eliminate SARC-CoV pandemic in 2003, which had no vaccine regulation for its treatment. This condition is same with zero vaccine availability for COVID-19. ${ }^{13}$ The study ${ }^{14}$ concluded that development of COVID-19 vaccine conducted by companies working to develop effective vaccines. CFR (Case Fatality Rate) is one of the disease severity indicators. The CFR does not tell about the risk of death but shows of real severity of disease. This study aims to compare case confirmation, mortality, and incidence mortality rate between Indonesia, Asia, and the world.

\section{Method}

The study design used a cross-sectional study with secondary data. The study population is the number of the time periods during COVID-19 infected by time-day. The study population as the number of days have been reported on diagnosis of COVID-19 disease based on the Ministry of Health of Indonesia have been estimated in Website with URL: https://covid19.kemkes.go.id/ and World Health Organization (WHO) have been estimated in WHO website with URL: https://covid19.who.int/ during the period of March 2020 to November 2020. Data samples were collected with the total population through inclusion and exclusion criteria. Data were collected for 236 days from March 18, 2020 to November 19, 2020. The variables in the research were decided in two variables. Independent variable is the area of disease which was determined as Indonesia, Asia, and world area. Dependent variable includes confirmatory, mortality, and mortality rate.

Confirmatory case is a number of confirmed case which has been shown in website through number of case/day. Mortality is a number of death case which have been shown in the website through number of case death/day. Coverage rate, i.e. a number of people with a confirmed COVID-19 compared to total people with Mortality rate, is shown formula bellow. 
Mortality rate
$=\frac{\text { No of people with death COVID-19 }}{\text { Total people with confirmed COVID-19 }}$

The sample frame was collected based on data which have been published on DepKes RI and WHO's websites. Data were collected from WHO website in https://covid19.who.int/ and DepKes Website in https://covid19.kemkes.go.id/ during the period of March 2020 to July 2020. Data samples collected were total population. The sample was collected as total sampling. ${ }^{15}$ Statistical analysis was performed using SPSS. Data were analyzed using ANOVA with confidence interval of $95 \%$.

\section{Results}

Data were analyzed for 236 days. The data have been published in the Depkes RI and WHO's websites. Based on the analysis, the confirmatory case, mortality and incidence mortality of covid-19 during the period of March 2020 to November 2020 were described on the table below.

Table 1. Description of Data of Confirmatory, Mortality and Incidence Mortality of COVID19 for Average and Standard Deviation

\begin{tabular}{lcccc}
\hline \multirow{2}{*}{ Variable } & \multirow{2}{*}{ N (Time day) } & Confirmatory & Mortality & Incidence \\
\cline { 3 - 5 } & & Mean \pm SD & Mean \pm SD & Mean \pm SD \\
\hline Indonesia & 236 & $1891.65 \pm 1468.412$ & $62.29 \pm 37.69$ & $.046 \pm .0326$ \\
Asia & 236 & $41146.94 \pm 34159.12$ & $635.36 \pm 453.68$ & $.023 \pm .0157$ \\
WHO & 236 & $211914.42 \pm 128689.95$ & $5279.71 \pm 1540.41$ & $.035 \pm .0231$ \\
\hline
\end{tabular}

Based on the analysis, the average of COVID-19 confirmatory case is $1891.65 \pm 1468.412$ in Indonesia, averaged 41146.94 \pm 34159.12 in Asia, and 211914.42 \pm 128689.95 according to WHO. Based on mortality of COVID-19, it averaged 62.29 \pm 37.69 in Indonesia, averaged $635.36 \pm 453.68$ in Asia, averaged $5279.71 \pm 1540.41$ according to WHO. The incidence mortality rate of $0.046 \pm \mathbf{0} .0326$ in Indonesia, averaged $0.023 \pm \mathbf{0} .0157$ in Asia, and averaged $0.035 \pm \mathbf{0} .0231$ according to WHO. The trend analysis of incidence mortality comparison in Indonesia, Asia, and WHO are detailed in the figure 1 bellow. 


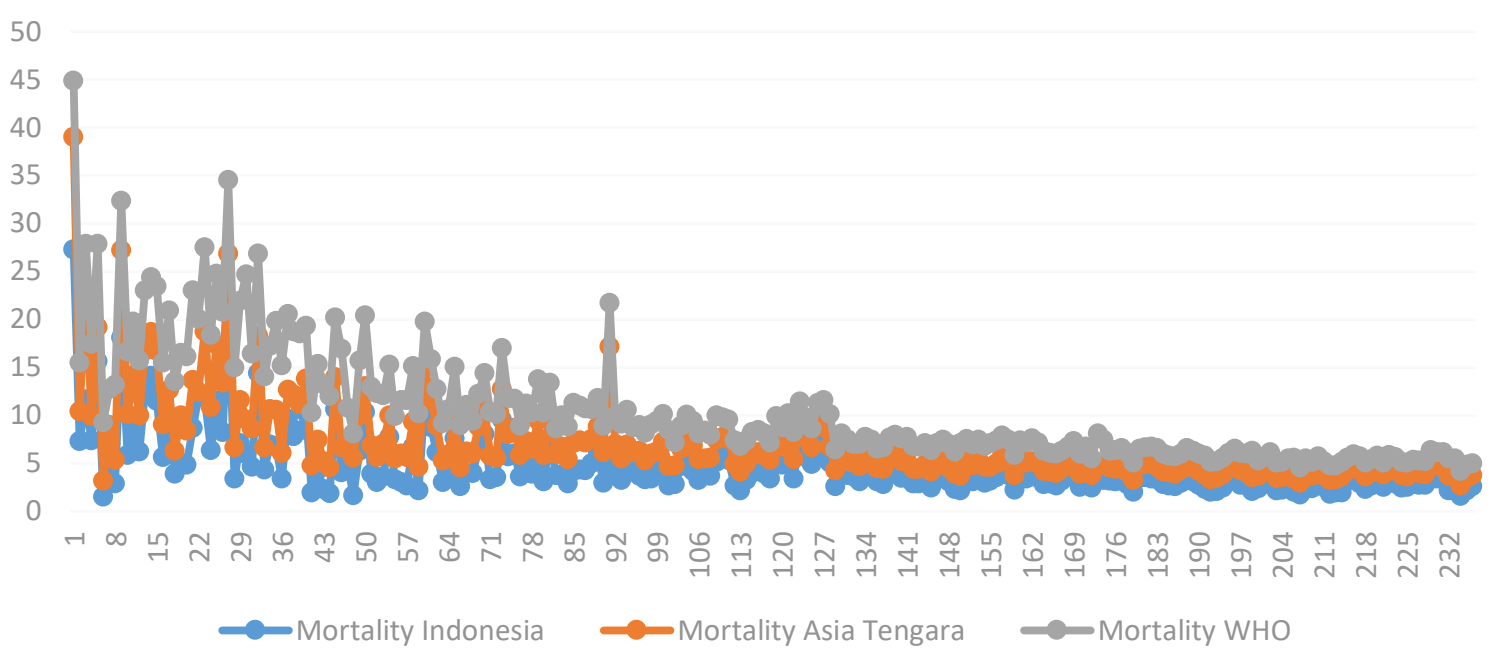

Figure 1. Incidence Mortality Between Indonesia, Asia, and WHO

Figure 1 showed that the incidence rate of mortality COVID-19 Indonesia is low compared to Asia and WHO while WHO is higher than Asia. The study showed that level of incidence mortality according WHO is the highest, followed by Asia, and then Indonesia. The different data of confirmatory case, mortality and incident mortality between Indonesia, Asia, and WHO are shown in table 2 below.

Table 2. Analysis Differences of Confirmed Case, Mortality, and Incidence Mortality between Indonesia, Asia, and WHO

\begin{tabular}{lcccccc}
\hline \multicolumn{1}{c}{ Variables } & \multirow{2}{*}{$\mathbf{N}$} & Indonesia & Asia & WHO & \multirow{2}{*}{ F } & p \\
\cline { 3 - 5 } & & Mean \pm SD & Mean \pm SD & Mean \pm SD & & \\
Confirmatory Covid-19 & 236 & $1891.65 \pm 1468.412$ & $41146.94 \pm 34159.12$ & $211914.42 \pm 128689.95$ & 497.90 & 0,000 \\
Mortality Covid-19 & 236 & $62.29 \pm 37.69$ & $635.36 \pm 453.68$ & $5279.71 \pm 1540.4$ & 2.246 .3 & 0,000 \\
Incidence mortality & 236 & $.046 \pm .0326$ & $.023 \pm .0157$ & $.035 \pm .0231$ & 51.962 & 0,000 \\
\hline
\end{tabular}

Based on table 2, the difference is significant in confirmatory case between Indonesia, Asia, and WHO with $\mathrm{p}<0.001$. Based on the mortality, the difference between Indonesia, Asia and WHO is significant with $\mathrm{p}<0.001$ and the incidence rate difference between Indonesa, Asia, and WHO is significant with $\mathrm{p}<0.001$.

\section{Discussion}

The study showed that the average of confirmatory case and mortality are higher according to WHO's data compared to Asia's and Indonesia's data, but the incident mortality in Indonesia is higher compared to WHO and Asia. This situation caused that confirmatory data in WHO for all 
population in the world include Asia and Indonesia. The indicator of mortality rate is divided between confirmed death and confirmed case during pandemic. The mortality rate is not an indicator for risk of death, but case fatality rate reflect the severity of the disease. Study ${ }^{16}$ showed that the indicator for severity of disease refers to occurred death cases. The indicator of disease assumes that the death and total case are lower compared to death and confirmed case. The assumption of best indicators for disease severity compared deaths to confirmed cases. The magnitude of the disease occurs during the outbreak. The number of incidence rate is important to compare the CFR indicator in different countries.

Based on WHO's data 202012, SARS-CoV-2 had infected 381,000 cases in 195 countries. Confirmatory cases are suspected in order with signs and symptoms addressed COVID-19. The history of COVID-19 is based on the previous study ${ }^{6}$ such as MERS-CoV and SARS-CoV before 2020 WHO named the novel corona virus (COVID-19). The mode of transmission compared to SARS-CoV-2 and MERS-CoV which is estimated to be $30 \%$ among household contacts and COVID-19 is higher. The previous study ${ }^{10}$ showed that the transmission among household contacts and strategy is urgently needed to prevent COVID-19. Study ${ }^{13}$ showed that the virus is more infectious than SARS-CoV. Study ${ }^{11}$ showed that transmission within the households is important part of COVID-19. COVID-19 is transmitted through droplets, contact and susceptible population. This condition caused the transmission to continue and hard to be decreased. The mode of transmission according to Study ${ }^{5}$ shows the mean transmission of COVID-19 R0 was up to 3.58 .

The high mortality rate is a contributing factor to COVID-19. In Indonesia, early July, the local transmission has the potential to contribute to mortality. Based on the data shown after lockdown, COVID-19 was increased. This situation caused local transmission to be done. The study ${ }^{4}$ stated that in early 2020, the central cases in China were approximately $92.9 \%$, but after February 2020 other countries COVID-19 cases have increased. The incidence of mortality rate was high for elderly, pregnant, and people with comorbidity population. The study ${ }^{3}$ stated that the fatality rate was 6.3 in April 13, 2020. In Italy, patients died an average of 78 years old. In Turkey, the case fatality rate was $2.1 \%$. The COVID-19 mortality was associated with multifactorial process and ages. The high mortality rate in the previous study ${ }^{14}$ showed that the $9 \%$ of patients died in 26 countries compared COVID-19 infection with mortality rate of $2.9 \%$. The study ${ }^{5}$ in Taiwan reported that $2.5 \%$ of the patients have died.

Based in the incidence mortality, Indonesia was higher compared to Asia and WHO. This caused the condition in Indonesia, Asia and WHO. The study shown that Indonesia has higher incidence rate of mortality compared to Asia and WHO. Indonesia has higher incidence mortality due to situation where potential local transmission has occured. Local transmission caused mortality incident. The factors increasing the incidence mortality such as local transmission, facility health service, and response of COVID-19 in local authority. The previous study ${ }^{4}$ showed 
that the mortality rate, incidence and death are significantly correlated with the population density and local transmission.

The disease record is implemented through disease caused droplet such as tuberculosis and COVID-19. The mode of transmission between tuberculosis and COVID-19 is almost the same. The previous study ${ }^{17}$ showed that droplet were the main focus of mode of transmission for both disease. The reduction strategy of COVID-19 in the previous study was offered through herbal intervention. The previous study ${ }^{18}$ shows that the intervention with herbal has potential to increase the immunology. This condition through herbal intervention decreased virus development in the body's organ, especially the lungs.

The previous study ${ }^{19}$ through the mode of transmission of COVID-19 in China that emigrated were the main focus of transmission. This mode of transmission condition to continue. The prevention through an epidemiological strategy approach ${ }^{20}$ which model the decrease of COVID-19 with the interruption of transmission of COVID-19 disease. Previous study in Bangladesh $^{21}$ stated that that the COVID-19 outbreak have impacted public's psychology and major depression in public. The study about COVID-19 in epidemic period ${ }^{22}$ that through some scenarios predicting that alarming deaths is important for early detection.

The strategy preventing the transmission of COVID-19 such as lockdown, vaccination, physical distancing, and other method such as quarantine. Study ${ }^{6,10}$ showed that the prevention of infectious COVID-19 very important in decreasing the disease transmission. Study ${ }^{12}$ which resulted studies across 16 countries shows lower virus transmission of [aOR] $0 \cdot 18$. Study ${ }^{9}$ showed that the early transmission COVID-19 means an incubation period of 5.2 days. The prevention of COVID19 with other approach such as vaccine. Previous study currently have no vaccine for COVID-19, but several countries have developed vaccine for COVID-19. Study ${ }^{12}$ showed that no vaccine against COVID-19 were available in early February, but several countries have developed vaccine after that time. Human COVID-19 targeted the addressed population such as the elderly. Many companies in many countries have developed vaccines. Study ${ }^{8}$ has reviewed previous study controlling inflammatory response for pathological virus.

Since the early of 2020, COVID-19 have infected and became the world pandemic. And after lockdown enforced by the police, COVID-19 transmission have increased. After the lockdown was ended, the potential local transmission was done. Local transmission is the main focus for national government after the lockdown was ended. Some health or medical workers have been infected through transmission. Previous study ${ }^{6}$ stated that corona virus was almost $17.7 \%$ through an incident mortality rate of $0.3 \%$. Study ${ }^{4}$ concluded that the COVID-19 outbreak was a clinical threat to the population, and the healthcare workers prevent COVID-19. 


\section{Conclusion}

The study concluded that there were significant differences between confirmatory case, death, and incidence mortality between Indonesia, Asia, and WHO. The confirmatory case and death were higher according to WHO and Asia compared Indonesia, but the incidence mortality is higher in Indonesia compared to WHO and Asia. Mortality rate of COVID-19 impacted the widespread transmission. The strategy requires efforts to reduce COVID-19 death, including physical distancing, hands washing, and wearing a mask. Further research on risk factors related to incident mortality of COVID-19 in Indonesia is required.

\section{Acknowledgement}

We would like to thank The Indonesia Ministry of Health for updating COVID-19 every time.

\section{Funding}

There is no funding for this research, and the funds used are the author's personal funds.

\section{Conflict of Interest}

The authors declare that they have no conflict of interest.

\section{Reference}

1. World Health Organization. Coronavirus disease 2019 (Covid-19) Situation Report - 72. Adv Sci Lett. 2020;23(6):5045-9.

2. Wenger PN, Halperin W, Ziga E. Public Health Surveillance for Bioterrorism. Beyond Anthrax. 2008; 10 : 253-278. doi: 10.1007/978-1-59745-326-4_13.

3. Bulut C, Kato Y. Epidemiology of covid-19. Turkish J Med Sci. 2020;50(SI-1):563-70. http://journals.tubitak.gov.tr/medical, doi:10.3906/sag-2004-172

4. Lai C, Wang C, Wang Y, Hsueh S, Ko W, Hsueh P. International Journal of Antimicrobial Agents Global epidemiology of coronavirus disease 2019 ( Covid-19 ): disease incidence , daily cumulative index , mortality, and their association with country healthcare resources and economic status. Int J Antimicrob Agents [Internet]. 2020;55(4):105946. Available from: https://doi.org/10.1016/j.jjantimicag.2020.105946

5. Lai C, Shih T, Ko W, Tang H, Hsueh P. Severe acute respiratory syndrome coronavirus 2 (SARS-CoV-2) and coronavirus disease-2019 (COVID-19): The epidemic and the challenges. Int J Antimicrob Agents. 2020 Mar;55(3):105924.

doi:10.1016/j.ijantimicag.2020.105924. 
6. Ye Q, Wang B, Jianhua MS, Junfen M, Shang S, Qiang MS. Epidemiological analysis of Covid - 19 and practical experience from China. J Med Virol. 2020 Jul;92(7):755-769. doi: 10.1002/jmv.25813.

7. Lauer SA, Grantz KH, Bi Q, Jones FK, Zheng Q, Meredith HR,. The incubation period of coronavirus disease 2019 (CoVID-19) from publicly reported confirmed cases: Estimation and application. Ann Intern Med. 2020;172(9):577-82.

8. Tay MZ, Poh CM, Rénia L, Macary PA, Ng LFP. The trinity of Covid-19: immunity, inflammation and intervention. Review. Nat Rev Immunol. 2020 Jun;20(6):363-374. doi: 10.1038/s41577-020-0311-8.

9. Li Q, Guan X, Wu P, Wang X, Zhou L, Tong Y,. Early Transmission Dynamics in Wuhan, China, of Novel Coronavirus-Infected Pneumonia. N Engl J Med. 2020;382(13):1199-207.

10. Wang Z, Ma W, Zheng X, Wu G, Zhang R. Household transmission of SARS-CoV-2. J Infect. 2020 Jul;81(1):179-182. doi: 10.1016/j.jinf.2020.03.040.

11. Chan JF, Yuan S, Kok K, To KK, Chu H, Yang J,. A familial cluster of pneumonia associated with the 2019 novel coronavirus indicating person-to-person transmission: a study of a family cluster. Lancet [Internet]. 2020;395(10223):514-23. Available from: http://dx.doi.org/10.1016/S0140-6736(20)30154-9

12. Ramanathan K, Antognini D, Combes A, Paden M, Zakhary B, Ogino M,. Planning and provision of ECMO services for severe ARDS during the COVID-19 pandemic and other outbreaks of emerging infectious diseases. Lancet Respir Med. 2020 May; 8(5): 518-526. doi: 10.1016/S2213-2600(20)30121-1.

13. Jean S, Lee P, Hsueh P. Since January 2020 Elsevier has created a Covid-19 resource centre with free information in English and Mandarin on the novel coronavirus Covid- research that is available on the Covid-19 resource centre - including this with acknowledgement of the origin. J Microbiol Immunol Infect. 2020;53(3):436-443. doi: 10.1016/j.jmii.2020.03.034.

14. Adnan M, Khan S, Kazmi A, Bashir N, Siddique R. Covid-19 infection: Origin , transmission, and characteristics of human coronaviruses. J Adv Res [Internet]. 2020;24:91-8. doi: 10.1016/j.jare.2020.03.005.

15. Susanto N. Besar Sampel Dalam Penelitian Kesehatan. Digibooks, 2014.

16. Jin H, Lu L, Liu J, Cui M. Complex emergencies of Covid-19: management and experience in Zhuhai, China. Int J Antimicrob Agents [Internet]. 2020;55(5):105961. Available from: https://doi.org/10.1016/j.ijantimicag.2020.105961

17. Kusumoningrum TA, Susanto N, Marlinawati VU, Puspitawati T. Hubungan Dukungan Keluarga dan Kepatuhan Minum Obat terhadap Kesembuhan Penderita Tuberkulosis ( TB ) di Kabupaten Bantul. J Formil (Forum Ilmiah) KesMas Respati. 2020;5(1):29-35. 
18. Oladele JO, Ajayi EI, Oyeleke OM, Oladele OT, Olowookere BD, Adeniyi BM. A systematic review on COVID-19 pandemic with special emphasis on curative potentials of Nigeria based medicinal plants. Heliyon [Internet]. 2020;6(9):e04897. Available from: https://doi.org/10.1016/j.heliyon.2020.e04897

19. Chen ZL, Zhang Q, Lu Y, Guo ZM, Zhang X, Zhang WJ,. Distribution of the Covid-19 epidemic and correlation with population emigration from Wuhan, China. Chin Med J (Engl). 2020;133(9):1044-50.

20. Susanto, N \& Weraman, P. Epidemiologi Kesehatan. digibook; 2014.

21. Ara T, Rahman MM, Hossain MA, Ahmed A. Identifying the Associated Risk Factors of Sleep Disturbance During the Covid-19 Lockdown in Bangladesh: A Web-Based Survey. Front Psychiatry. 2020;11(September):1-11. doi: 10.1016/j.heliyon.2020.e04897

22. Barbarossa MV, Fuhrmann J, Meinke JH, Krieg S, Varma HV, Castelletti N,. Modeling the spread of Covid-19 in Germany: Early assessment and possible scenarios. PLoS One [Internet]. 2020;15(9 september):1-22. Available from:http://dx.doi.org/10.1371/journal.pone.0238559 